\title{
DEBATES ON EUROPE: WHAT ARE THE PROSPECTS OF RUSSIA'S AND TURKEY'S EUROPEAN BID?
}

Igor Torbakov ${ }^{*}$

\begin{abstract}
The study discusses Turkey's and Russia's European bid within a broader historical context of the debates on Europe. The prospect of the EU enlargement's stopping indefinitely sometime around 2007 inevitably entails two major consequences. Firstly, a new dividing line will be drawn across Europe between the nations that will be integrated within the Enlarged Union and those that will not. Secondly, the countries that are left out but still regard themselves European - and this seems to be the case of Turkey and Russia -- will have to face a tough dilemma. These nations will have to either revisit the thorny issue of their own cultural identity or push for reinventing the concept of Europe. Given the fact that the idea of Europe can be defined in a variety of ways, the second option is more likely. Thus, even if the enlargement process grinds to a halt at some point in the coming decade, the debates on Europe will continue.
\end{abstract}

As the NATO and EU enlargement summits closed late last year, the commentators started arguing - and apparently not without reason - that "we are entering the endgame of the EU and NATO enlargement process." If the analysts' assumptions are correct, then the ncw round of debates on what European community really is are all but inevitable. Indeed, if the process of building the "United Europe" is completed with the accession of 10 more Central and East European nations, and Brussels, after embracing the newcomers, shuts down the gates for good, the lofty task of the romantic early 1990s - that of fashioning "whole and free Europe" - will be only partially fulfilled. To be sure, all the EU member-statcs, including the new entrants, are free nations, no question about that. But will the EU after its

'PhD, Consultant, EurasiaNet, Open Society Institute (New York) 


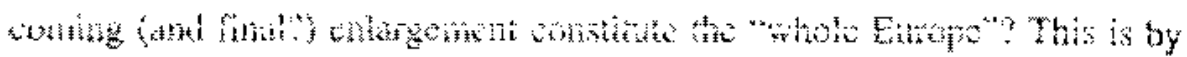
no means an idte question. In fact. it brings us to an even more funtumentai queries, stch as: Which countries und on what grounds can be regarded European? Where are Europe s borders? And hatly, what is Eumpe? for if

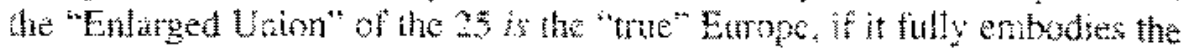
"Europern idea," then any nation that thinks it belongs, pengraghically ander historically, to Eufope bet is cumenty not an El nember or a

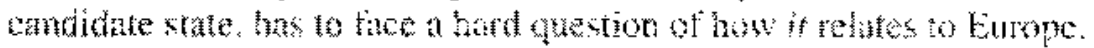

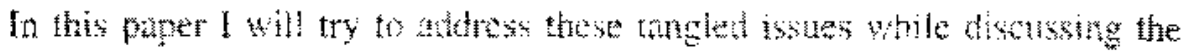

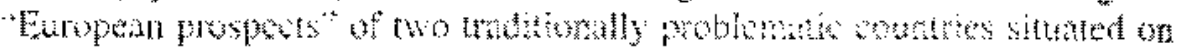
Lumpets periphery - Tukey and Rasia. The. Turky's and Rusials

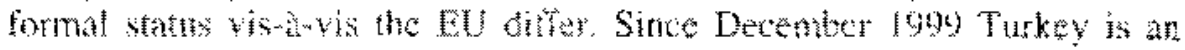
officially recognized andidate state, wherens Russia has mer seriously

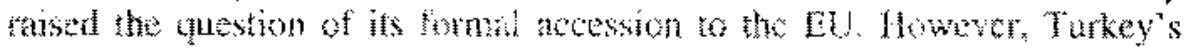

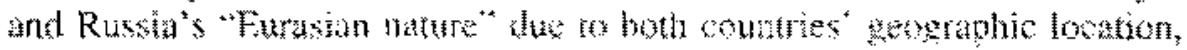

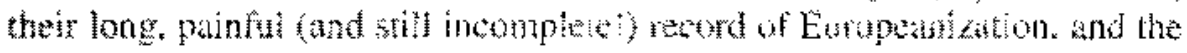

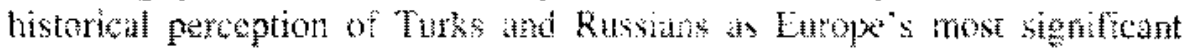
Others basically put these tho nutimens on the same frage. It is not a meret

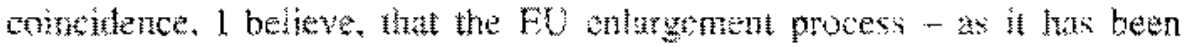

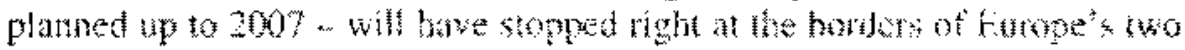

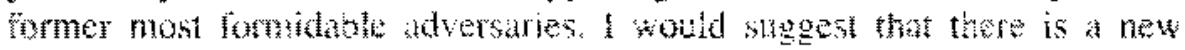

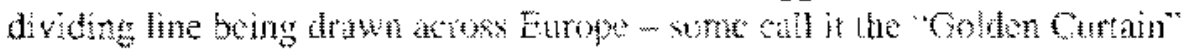
- separating those countries that are being incorpotines within the $\mathrm{EU}$ from those that are not. What is aven more signilicant. some commentators arge, is that "this new line acros Europe is jor just eonomic and staterion but

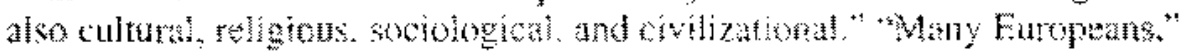

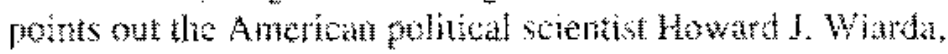

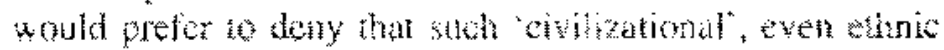
and ratal, criteratare being used to decte who geis in and

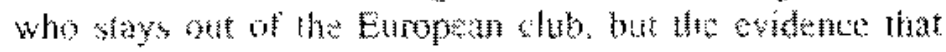

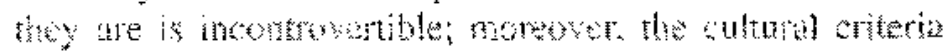

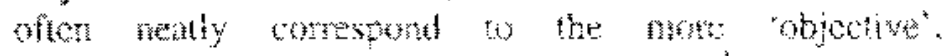

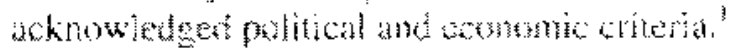

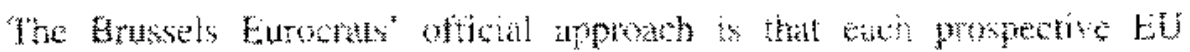

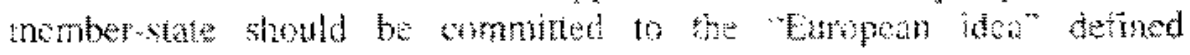

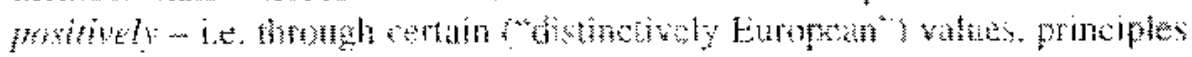

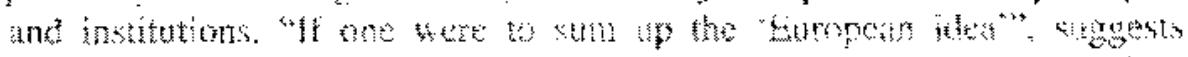

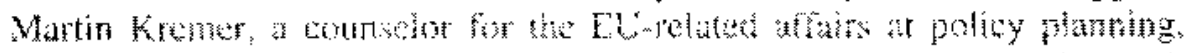

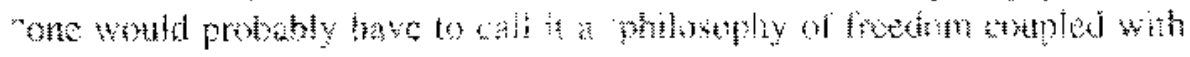


practical solidarity, organizing society and intemationat relations along democratic lines, on the basis of the rule of law." In operational terms. continues the official, the Copenhagen criteria san provide the best basis to translate such a conternpotary view of Europe into practice. "There is, however, a much older and more taditional way of defining Europe negativety - i.e. in relation to opposites. In an article on national identity and the idea of European unity, Anthony D. Smith argued that

Identities are forged out of shared experiences, memonies and myths, in relation to those of other collective identities. They are in fact often forged through opposition to the identities of significant others, as the history of paired confict so often demonstrates. Who or what, then, are Europe $s$ significant others?

It is this negative denition of European identity that ultimately shapes a political decision on who gets in and who does not. Quite symptomatically, the same Martin Kremer tas to acknowledge that

Present [EU] attitudes towards Turkey, for instance, are clearly coloted by the fact that, well into the nineteenth century, the Otroman Empire was regarded as Europe's archenemy. Perceptions of Russia mand 10 a lesser extent of Ukeane - are obviously influenced by the fact that [in the] last century they used to be seen is only superficially European.

Within this context, it would be worthwhile to briefly explore the history af intellectual struggle for the "European unity" - in other words, a record of attempts by the some brightsat minds to exlend the notion of "Eurepean civilization" to the eastern par of the Old Continent. The puticular significance of the EU eastward enlargement, in my opinion, lies in the lact that, institutionally, it will haye crowned this intellectual process of entarging Europe's mental map. By welcoming the Eastern Europeans in, the EU underscores their "kindred spirit:" their "eivilizational belonging" to the "rea" Europe. As one abseryer succinctly put it, in Central and Eastern Europe, joining the European Unim "is not just about agricultural quotas; rather, it is a civilizational issue." By the same token, a rather lukewarn attitude of the EU towatd potential Turkish - and, theoretically, Russian - mumbership should be explained, to a large extent, by cultural and civilizational considerations. Turkey and Russia have probably ceased to be viewed by Europe as geopolitical adversaries but are still being perceived as cultural allens, others. Thus, in the nedium and probably even long-term 
perspective, an answer to the thomy question of where Eutupe now ends appotars to be wore or less clear. Europe ends atong the eastern border of the "Enlarged Union" of the 25. Tukey and Russia are trost likely to find themselues on the other side of the Galden Cuntant

\section{Furope : elusive delintion}

"Extrope" tells us the contemportry historian of the Old Continent, "is a relatively modern inda." Howswer, add he, one has to kep in nind that its conten is guiti controversial: "hle gemgraphical, cultural, and political pamaneters of the Eurepean cormmnity hate always remamed open to

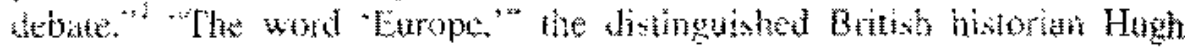
Seton Watsan once neted "has been used and mistsed. interpreted and misinterpreted in so many diferent metnings as almost any wad in any hanguge. There have beer and are mony Europes.." The writer and critie Fritz I. Raddate has coned a maxim that jubably sest rellows to what extent the concept af Europe remun indistinct and the menning wate: "A

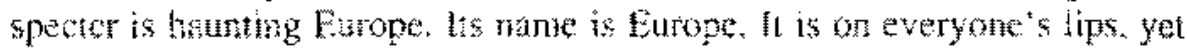
no one defines it."

Our tatk is tonlikely to betne any casier if we try to deal with the various parameters of "lurope" one by one. For intiance, what about Europe's geographical limits? Geotraphers comentionally describe Europe as nothing but a peringuta of Asta. This tefinition the entinent folish scholar Gsar lateck pointed out, "creates the inorescon that Enope's limits are easy to define. But even from the morely geographical point of view steh an impression is misleating." For axample. the notion at the Urals as the boundary bowcen Europe and Asia is a quite recent idea dating back from Peter the Great's time. Morewer, it was a chasical case of "ideological contruction of geographical space." as Marc Bassin persuasively showed us in his semina article. "The frontice on the Urats has been critictzed by a

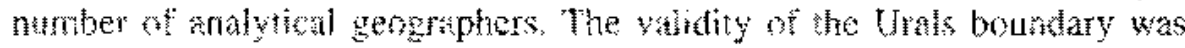
also questioned by such inflental thinkers as Amold Toyntese and Hallord

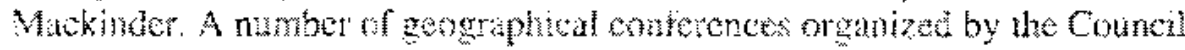

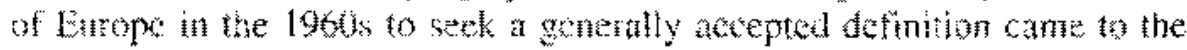
conchion that Eurepe truld be considared a separate tontinch only if human activity in terms of seftlement pattems, history, economic, caltural, anf polntical the wore taken into account. To make malters mote complex,

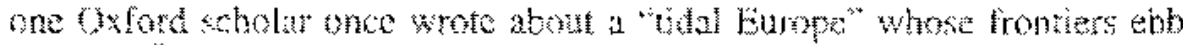
and how." 
The attempts to define "European history" appear to be no less fintile than the exetcises in trawing its geographical borters. In the mid. $1980 \mathrm{~s}$ the joumal history Tolay organized an enquiry: a number of distinguished scholars were to answer a question "What is European history?" Most respondents fatied to give a clear answer. Tet the reply of one contributor. A.J.P. Taylor, was particutarty revealing:

European history is whatever thc historitan wants it to be. it is a simmary of the wents and ideas, political, religious, mititary, pacitis, serious, romantic, near at hand, fat away, tratgc, conic, significant, meaningless, anything else you would like it to be. There is only one limiting factor, It must take place in, or flerive from, the area we call Europe. But at 1 am not sure what exatly athat area is meant to be, 1 an protty well in a hazte abont the rest.

This brief discussion is aesigned to demanstrate one key point, namety the tremendous ambiguity of the very concept af Europs. Two importart concusions flow out of this thesis. Firsty, in each particular historical period the question of "who gets in and who stays ou" was punarily political question resolved by a relatively small group of the continents core nations with the "impecable European credentials." Secondly, the notion of Europe has not been static but has been remade, revised and reinuentef through the course of history. There has indeed been not one bit ratter, in the words of Seton-Watson, many Europes.

Since the time when the concept of "Europe" weplaced the earlier concept of "Christendom" (cometime between the fourtenth and eighteenth centuries) and until the post World War 1 era Euroge was essentially associated with the Westem Europe or sifmply the "West." The "chosen tragnents of the Peninsulas, as one renowned stutient at the iscue has apty put it, appropriated the exciusive right to be designated as Euroge. Among the sculpures surounding the Albert Memorial (1876) in London is a gromp of tugures symuolizing "Entope." It consists of only fom figutes - Britain, France, Germaty, and Italy. The htstorical scholarstip neatly reflects this "exclusivist" attitude. The French historan and stateman Francois Guizon in his The Hitstory of Cinfization in Europe (1828m 1830$)$ explainet the supetionty of European civilization basting his argument furst of all on the history of England and Fance. The outstanding German historian Leopold yon Ranke in his History af the Romance and Gemantc Peoples (1824) adced Germans and labians to the European peoples par excelunce. lo the presace to his study he declared his conviction 
that the complex of Christian peoples of turope is to be considered as a whole, as one state, otherwise sne could not propetly understard the enoment differtuce that exists between the occidental and the oriental word. and the stedt shilditi; that exists between the Romance and the Gemanic Peoples.

"kanke." somments the Donish scholat Peter Bugge. "hore remoed the

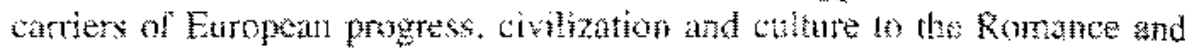

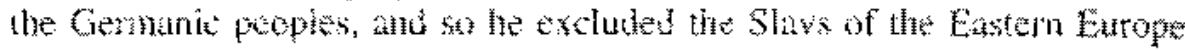

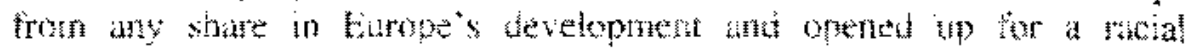

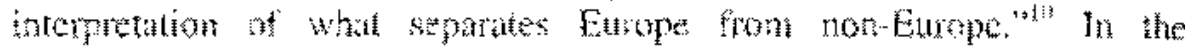
discounes on the history af Furope writen between the end of the nineteenth and the nidule of the rwentich centiry one is unitely to find Ponugal, Spain, or Scandinavia. just us there will be no Polud, no

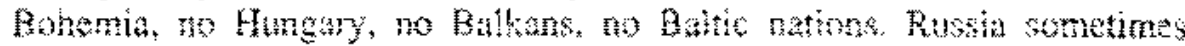
may be included and sometimes may be excluded. There is definitely no Tukey. The authors of those hitory book appar to have atecoted the idea

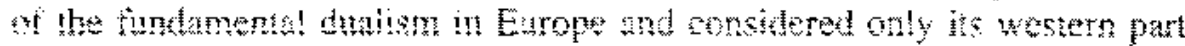
retlly lunepean. The great Swiss historian Gonzage de Reynold

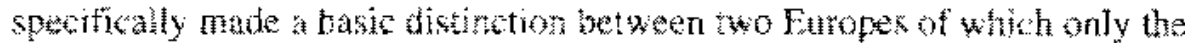

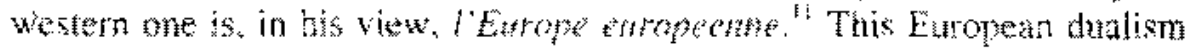

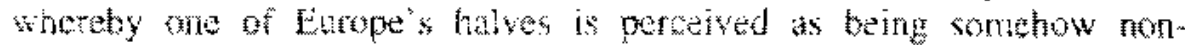

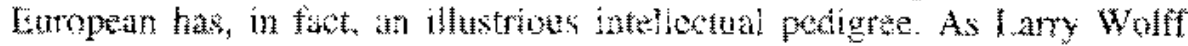
has demerstrated in his andite book a "semingientulized" Eastern curope was "invented" as one of the "tute" Eurone"s ithers by the philosophers of the Enlightenment. This "non-Eurspean" patu of Furong gudually gave way to the real "Orient" heginning somewhere in Russia and the Otoman

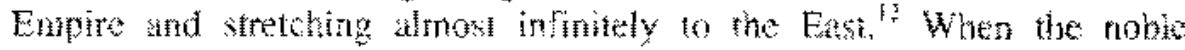
Frenchman Loths-Philippe de Segur was traveing acrose East European

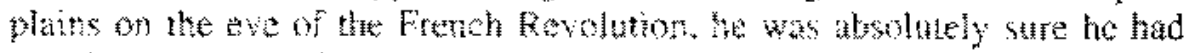

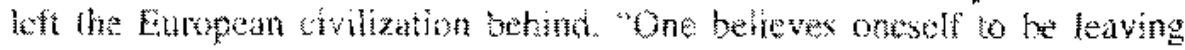

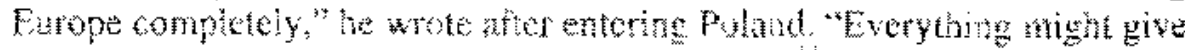
the impression of rtreting ten centures in time "In the hoinning of the

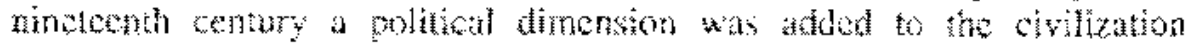

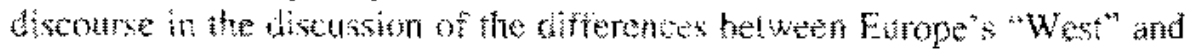

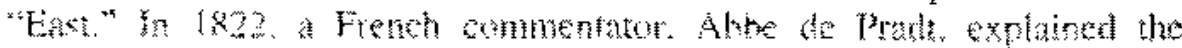

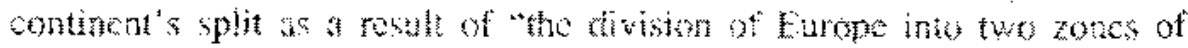

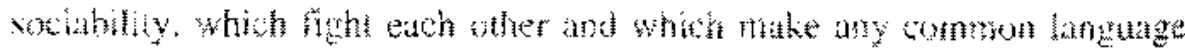

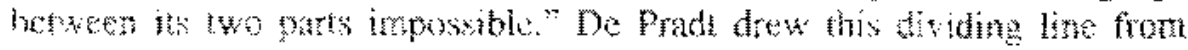

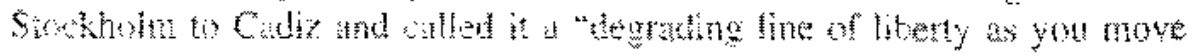


closer to Asia." "The perception of the "underdeveloped" and "uncivilized" Eastem Europe persisted well into the nineteenth and twentieth centuries. Westem Europe's condescending attitude toward the East can easily be discerned, for example, in that line from My Fatil Lady when Professor Higgins proclaims that "she was bon hungarian," which atways brings down the house with derisive langhter.

\section{Debate on Eastern Europe}

Arguably, it took almost two centuries for the elites of the continent's leading powers to have overcome "the parochial view of a Europe based exclusively on the prosperous west," In the twentieth century, there were three prominent European thinkers who, I belieze, bad made a particularly important intellectual contribution to the bridging of the grand divide between Europe's "West" and "East." They are Oscar Halecki, Hugh Seton" Watson and Norman Davies. Halecki, a Polish scholar who later emigrated to the United States, as instrumental in shaping, in the inter-war period, the idea of "East-Central Europe" - a concept that would become so popular among the East European dissidents in the 19705 and $1980 \mathrm{~s}^{16}$ In the aftermath of the First World War, this newly inyented notion of "EastCentral Europe" was designed to describe the "successor states" - from Finland and Poland in the north to Yugoslavia in the south - that emerged from under the rubble of three imperial powers - Russian, AustroHungarian and Otoman. The concept's primary political task was to underscone the fundamental European ness of the region. "It appears that some countries which are sifuated in the eastern, or at least the east-central, part of Europe have particulaty close ties, cultural and even political, with the Latin West of the continent." contended Haleck.. "The lifespan of the domain that the idca of "East-Central Europe" intended to describe, however, was quite short. "A pro-Westem buffer zone between Soviet Russia and Getmany, it was the product of exceptional circumstances: the powet vacum created by the sirnultaneous World War I collapse of Germany and Russia. And it lasted only as long as these exceptional circumstances did." ARer the Sscond World War, in 1950, just a year befote a momentous step was aken to set up European Coal and Steel Community. Halecki published his important stady tilled the Limits and Divisions of Eurapean History. In this magisterial work Halecki has formulated his major thesis in the most straightforward way. He forcefully argued that, despite all the vagaries of its unfortunate history, Eastern Europe was no fess European than Western Europe - that both alike wer: integral part of one great community of peoples, sharing the same spiritual 
ideals, poifieal values and mulumal fratitions, "The term Western civilization," asserted Halecki,

entails the powctichl Innitation of European history to

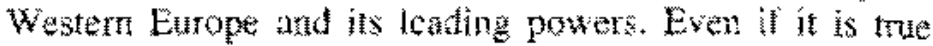
that in some pentods thase Western powers piayed a

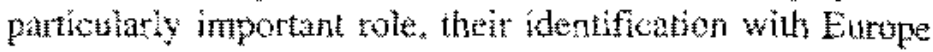

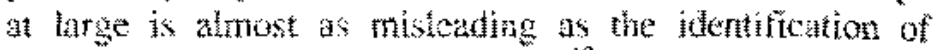
Eurotean history with word tristory.

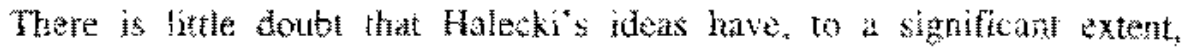

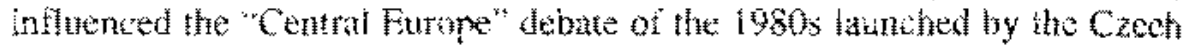

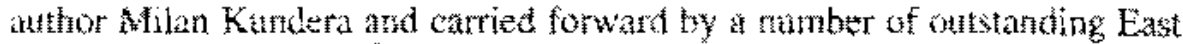

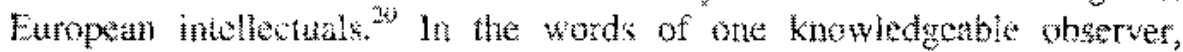

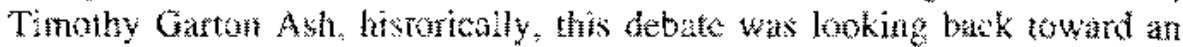

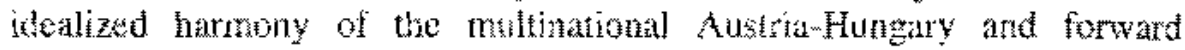

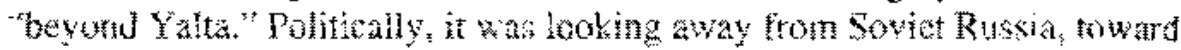

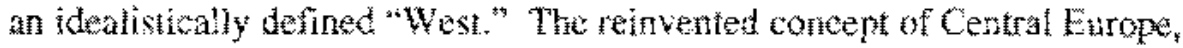
wrota in 1989 Jaxques Rapnik, a Senim Fellow at Fondation Nationale des So

represents, on the one hand, an ascertion of a bisiorited and coltural ifentity distincer forn that imposed for forty nive yoars on the nations of the whet hat of Etrope by the Sovidet enpira. On the other Hind, it is stso pats of the continuige political search for an atternative to the partion af Emope.

On the onsosite situe of the Iron Curtain, a fundormental iden of Europen

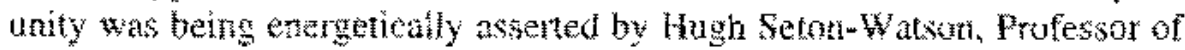
Ressian Fistory at the London School of Slavonic and East European Suldics. In April 1985, he delivered a lecture at the Royd Institute of

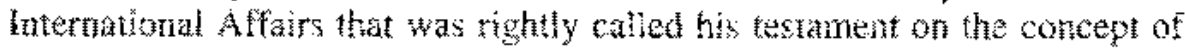

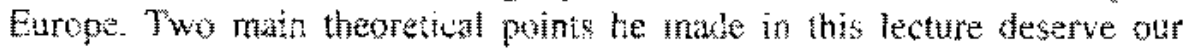

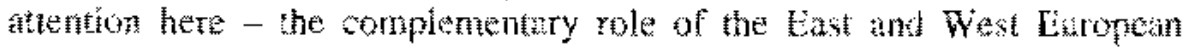

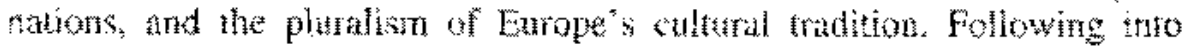

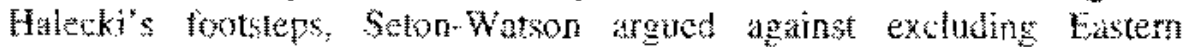

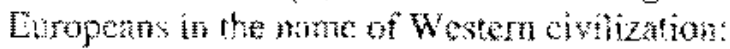

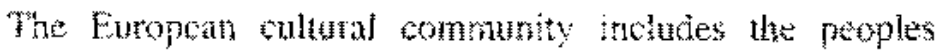
living beyond Germany ard Italy. something in no way

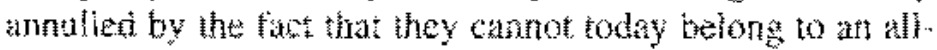

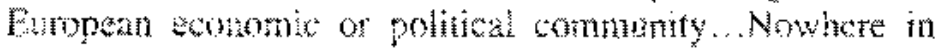


the world is there so wide-spread a beliet in the reality, and the importance of a European cultural communty, as in the countries lying between the EEC and the Soviet Union. ${ }^{22}$

Furthermore, Seton-Watson stafed that European culture was by no means a monolithe one:

The interweaving of the notions of Europe and of Christendom is a fact of History which even the most brilliant sophistry cannot undo... But it is no less true that there are strands in European culture that are not Christian: the Roman, the Heflenic, arguably the Persian, and (in modern centuries) the Jewish. ${ }^{2}$

It is noteworthy, though, that he was far more cautious, if not skeptical, about Islamic heritage: "Whether there is also a Muslim strand is more diffieult to say."

Noman Davies, who proudly calls himself Hugh Seton-Watson's intellectual disciple whose legacy he follows "most closely," whote his authoritative Europe: A Hisiony after the communim"s collapse in Eastem Europe and the Soviet Unon's unraveling. By the time his book came out, the discussion on the EU exstward enfargement was well under way. Being one of the Great Britain's most eminent scholars, Davies appears to have significantly influenced the Europe debate in it critical phuse. To be sure, his book didn't contain policy recommendations, but it still carried quite a lot of intellectual weight. As the London Review of Books put it, "after Davies, it will never be possible to write a history of Europe in the old way again." Faithful to the intellextual tradition laid down by Halecki and Seton" Watson, Davies calls for a thotough revision of what he labels "the established canon of European Culture." His argument stresses two fundamental points: East Europeans' kinship with the "West," and Europe's cuttural diversity. "The title of "Europe," contends Davies,

like the earlier label of 'Cluristendom'... can hardly be arrogated by one of its several regions. Eastern Europe is no less European for being poor, or underdeveloped, ar ruled by tyrants... Nor can the Eastern Europe he rejectef beciuse it is "different" All European countries are different. All West European countries are difierent. And there are important similarities which span the divide... Their fundamental unities are no less obvious than their znarifest diversity. ${ }^{24}$ 


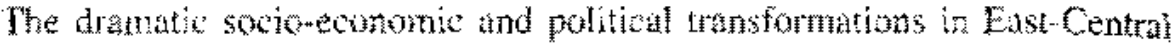
Europe over the last decalle coupled with the strategie interests of Earope's "West appear to have lent trementous authority to the dea of the

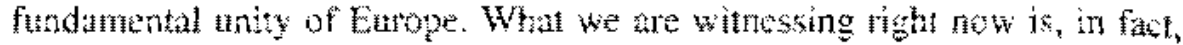

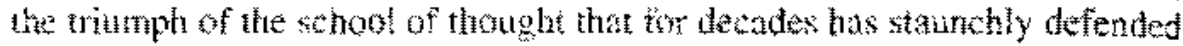
the Eas Europens" "unaliendible right" to the "true" Eutopenn-ness. The incorparation of Europe's "East" into the EU has sented the controversial isste of the "daterner" historieat and cultunt belonging. The decision on their formal atcession is at the sante time an atot of their offich recognition ats "real" Europems.

\section{Russia and Turkey: Europe ${ }^{*}$ periphery or outsiders?}

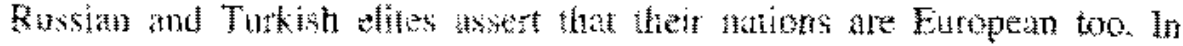
Russia's case the elite's identicticatior with Europe dates back to the eishtenth century. Peter the Grat had "cut out al window on Fimope," as

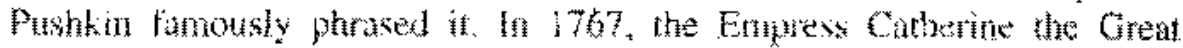

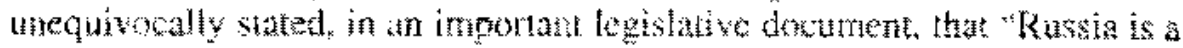
Eumpen Power." Turkish chime to Etrotean identity are much more recent and tinged with a cerain sente of ambiguty. Turkey formar minister of breign affuts smal Cem has areded that ho contry possesses

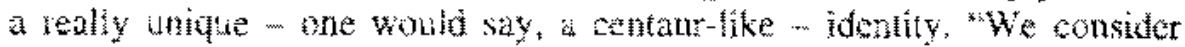

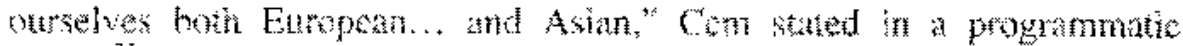

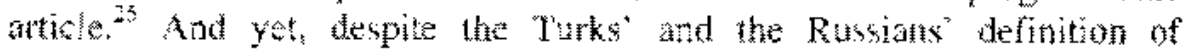
themsulves as Eurgeins and their attempts at aldopting Europears

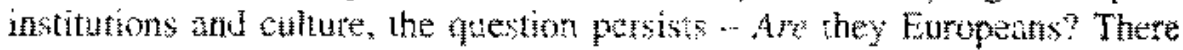

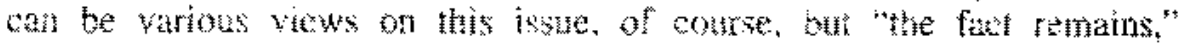
Poneloge D. Safoleas correctly points out, "bat imil Eumpens see them

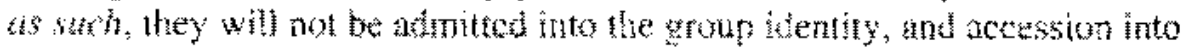
the Eutopean Unim will consistently be postponed and possibly eventuatly denied outrisho."

Now, it wowl he conly proger to have a bref look at how Rusia and Turkey

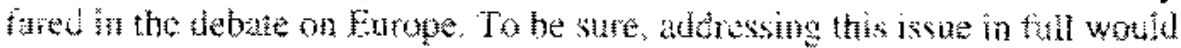
demand a separate bie study: hem I will consciensly lini? myscif to the

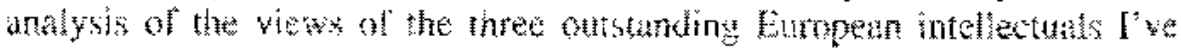
refered to ahove how wer. we will protably get aven a more revaling poture since in the renteth contury those whath have ben the most

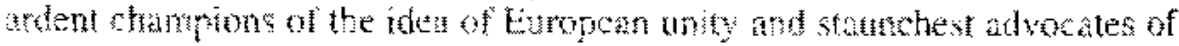
the Lint Lutopan apeoples. 
What is truly remarkable is how very similar are the views of Halecki, Seton-Watson and Davies on the ssue of Russia's and Tukey"s relation to purape, The thing that immediately catches an observer"s eye is that Russia's and Turkey's socio-cultural peculiarites semed to be too difficult to stomach even for the nost broad-minded proponents of the European cultural diversity.

Oscar Haleckis views on Turkey are very traditional, stemming from the European historiographical and, broader w cultural canon of the ninetesth century. For him, the Ottoman Empire the never discussed the Republicts

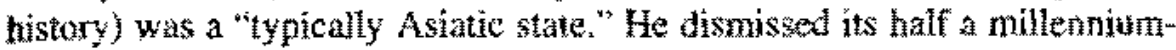
long engagentent with Europe as a rude and ninous intrusion. "From the European point," argues Halecki, "it must be observed that the Ottoman

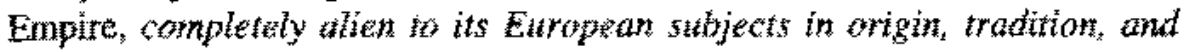
religion, fat from integrating them in a new type of cullure, brought them nothing but a degrading toreign domination which intamuted for approximatsly four hunded years their participation in Europaan history." In his vew, the physical presence of non-Eutopean - and even antiEurpean - Ermpire of the Turks in Southern Etrope had only led to one unfortunate devolopment - tramely, a protracted excluston of the Balkan peoples from the community of European mations and trom the body of European history. "During these centuries lof occupation]," assented the Polish scholar, "the European Fronture of he Ottoman Empire... was the

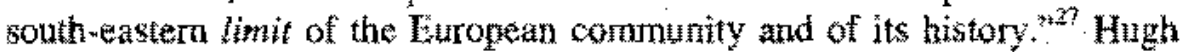
Seton-Watson's approach semp to be a little bit subtler than that of Haleck's. He, as we remember, was even musing on the probable presence of a "Muslim strand" in the European cultural heritage. Ho has shrunk, however, trom giving a definitive answer to this controversial question. The most reverating, though, is Noman Davies' stance on the issue. 'The atthor who has beren so teonoclastite and innovative in deathe with East Curopean history has proved as traditional as any of his many pradecessors in interpreling Turkey's relations with Europe. In Davies picture of Europe, Turkey and its history (both Otoman and post-irnperial) are absolutely marginal. He never even poses conceptual question of how Turkey relates to Europe. There is no doubt that for the British anthor who has offered the newest interpretation of the continent" history 'Turkey is a clear ontsider. Suffice it to mention that in the Index to the 1400 page volume hat is being touted as the "lates wort of the European histoniography" there is just on (1) entry on the Republic of Tukey. In Davies" eyes, Turkey is definitely chon European. "The border of the shrinking enclave of what came to be 


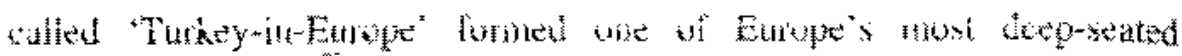

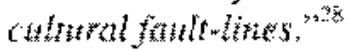

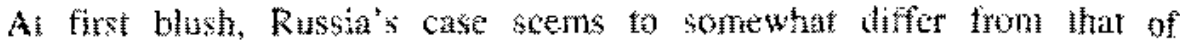

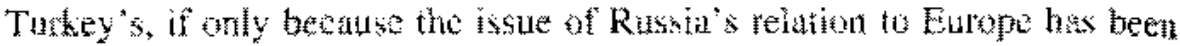

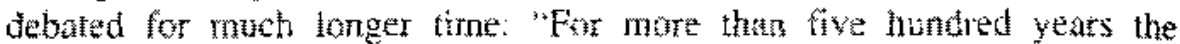

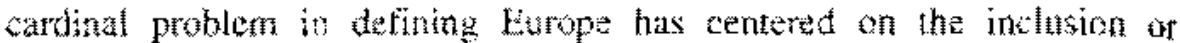

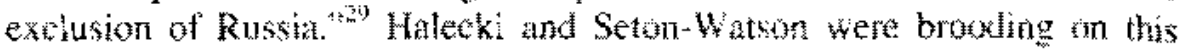

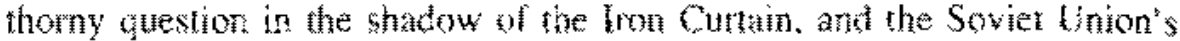

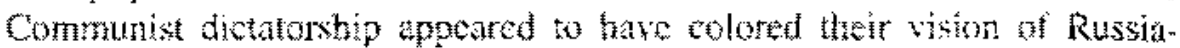

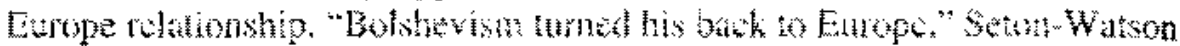

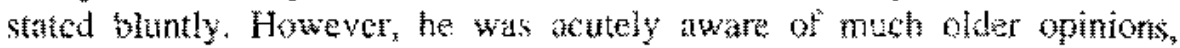

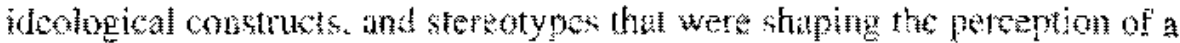

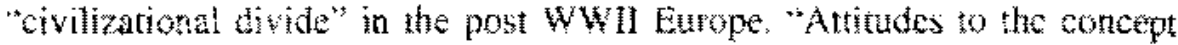

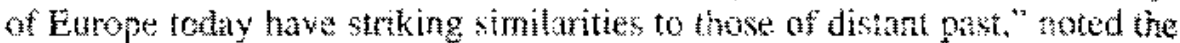

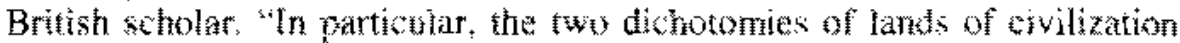

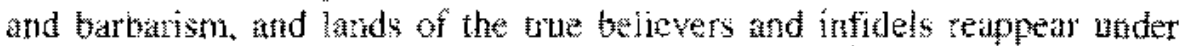
new atames an boton sides of the Litheck-Treste line."

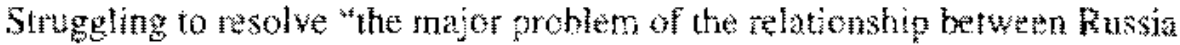

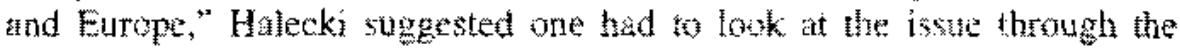

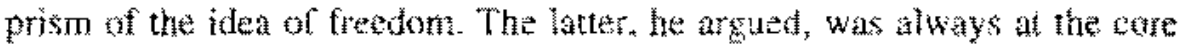

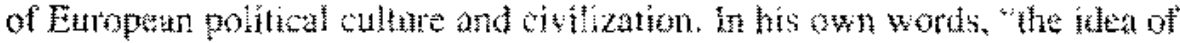

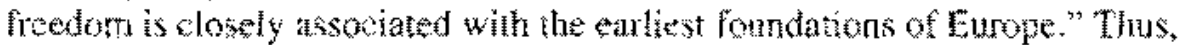
Maleck contifned,

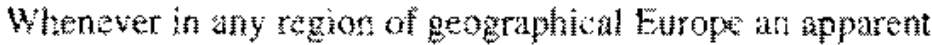
solution at the basto political tusues has ben reached by simply suppressing frewom, that segion has beton placed, at least temporatily, outside historical Eurowe.

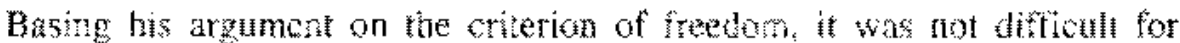

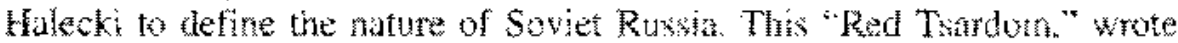

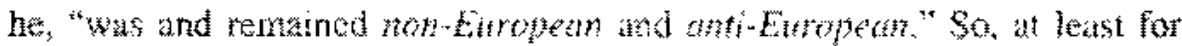

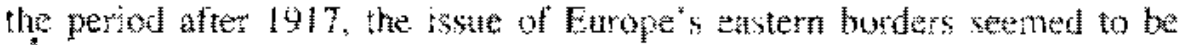

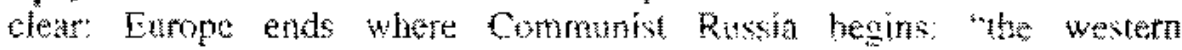

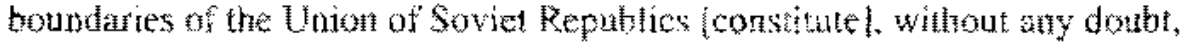

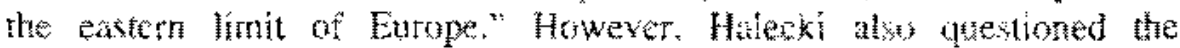

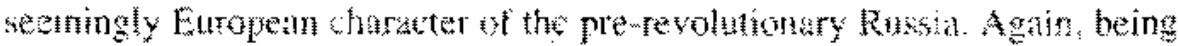

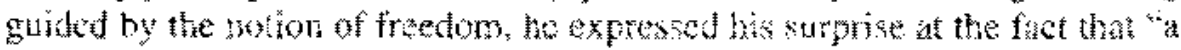

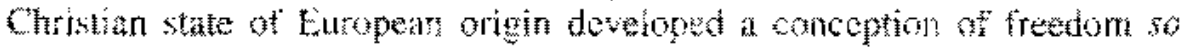


diferent from the Elapopen as to be practictly its negation, with despotism and molitisuto anarchy ats alternatives,

Similarly, for Seton- Watson, the most peculiar feature of Russin throughout ths hetorical existence is a lack of political pluralsm. One single factor tuat dominates the course of Russian history, argues the schola, is the principle of antocracy. "In this respect Russian history difers from that of all western European countres, except perhaps Spain. The Western nations were formed in a long struggle between the monarchicat potzer and the sociat eltte.. Whatever one may feel of the merits of the confending parties, one fannot demy the existence of the struggle... In Russia... it hardly existed." Here is an irony (or tragedy?) of Russian history. Every importan sociat charge -- including several major fits of Curopeanization -... "wate due to monarchical power." However, the progressive Europeanizing reforms hud to be carried out within a clearly non-European sociopolitical context. "There was nevar any suggestion that government by atoctat should give place to goveriment in whin power would be divided betwen chasses and instututions." Russia would always find itself in the vicious cycle of bungled reforms styled on the European model.

In Davies" marrative, Russia hizutes much more prominently than Turkey. In a theoretical introduction to his book the autwor does ponder the quastion of the ralations between Russia and Europe. And yef, in its treatment of Russiam Europe interplay this otherwise pioneering study sticks to the tradifional approach furmty estabished in the Europsen (and, broader, Westarn scholarship - almost like it toes with regard to Turkey! Which is, of course, both symptomatic and revealing: a leading European spholar arguing at the very end of the wenteth century that Russia -- whother Tsarist, Sovies, or post-Communist - has been a "bad fit" for Europe, Davies appears not to be influenced by the newest revisionist approach of Martir Malia who aimed to demoncitate that Fussia was a "normal" Exwopean country set on ath of political and economic converyence with its more advanced western neighbors. "Thuroughout modern hisury", contends byves, "an Orthodox, autocratic, economically backward but expanding Russia" could hardy quatify as a "irue" European state. Even after the collapse of the Communist regime, "skepticism about Russia's European gualifications continued to circulate both inside and outside Rustia." There are an least thre major "drawbacks" that in Daviess" opinion, kep the present-day Russian Federation outside Europe. It us "utot a cohesiye nation-state, ripe for democracy" it is "stinl a multimational 


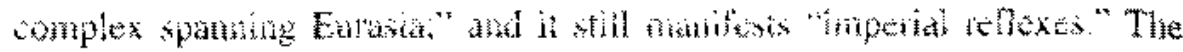

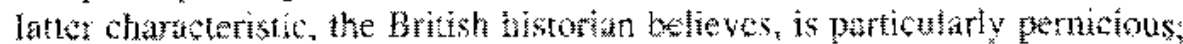

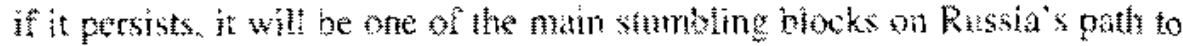
Emoperan inegration. "Unless [Russial could find ways of shedding the

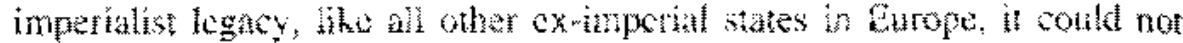

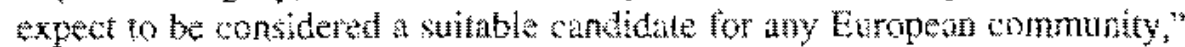
states Dituitis.

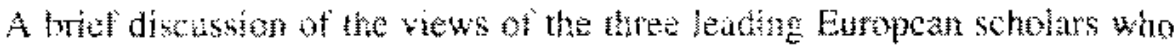

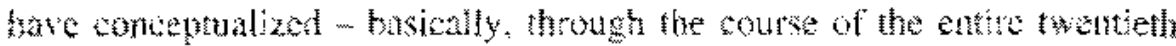

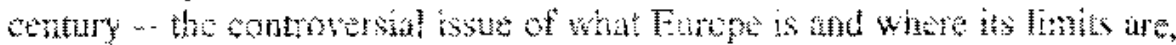

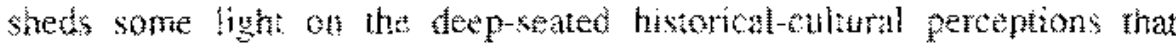

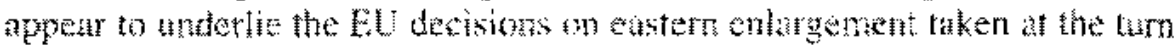

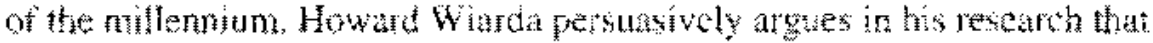

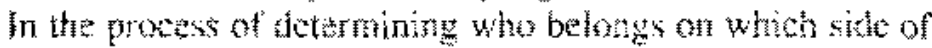

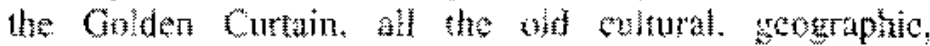

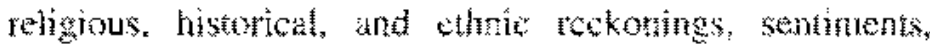

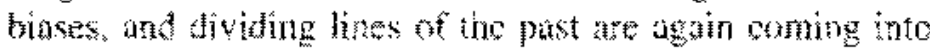
piay. 35

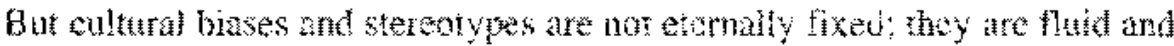

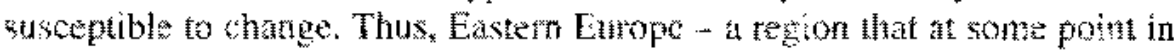

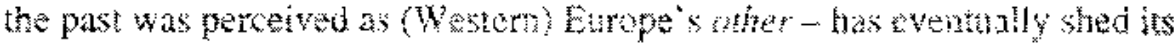

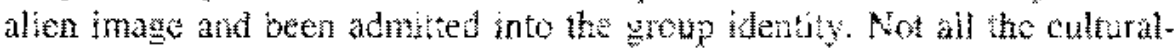

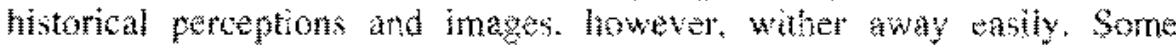

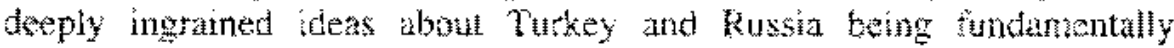

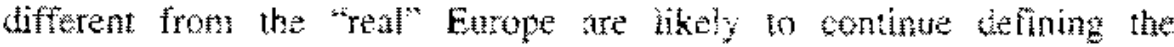
confizuration of the FU eastern fontiter.

\section{Can the Guropeamation profect succed?}

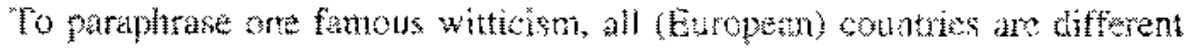

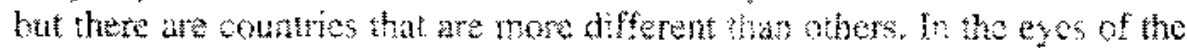

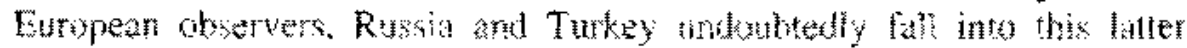

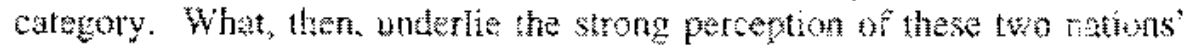

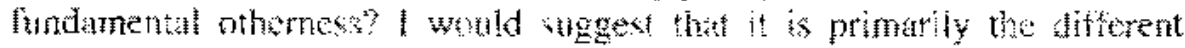

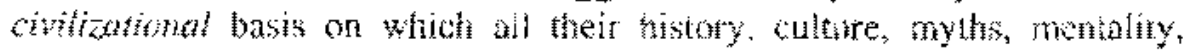

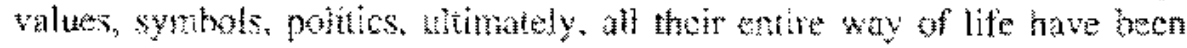

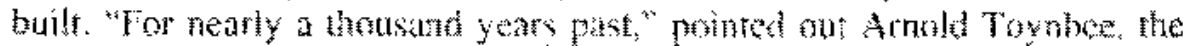
Russians have.. been members. nut of our Wotern civinzation, bat of the

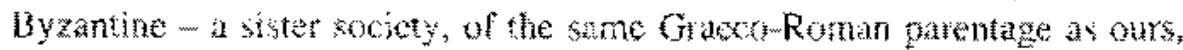

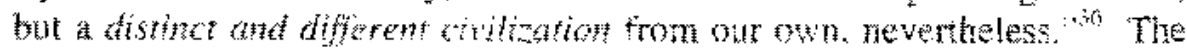


Turks, being Muslims, have naturally been regarded in Furope for centuries as an even mote distinct, distant, and allen civilization. The outstanding Belgian historian Henri Pirenne, while describing in his atolaimed A History of Europe the first military contacts between the Europeans and the advancing Turks in the Balkans, made a characteristic temark: "There was only one possible means of stopping the Turks, and that was to absorb them into Western civilization; but since they professed stam, this was simply unthinkable." Historically. Turkey and Russia were not born European, the argument goes; rather, at one point they decided to become European, inus turning themselves into the Europuanizing states. However, for the countries with a long historical tradition, to reinvent themselves is not an easy task. Any Europeanization project inevitably causes deep splits and ruptutes in the naton's social fabric. Ultimately, a Europemizing country ents up becoming what some political scientists term a "torn state." It i.s these considerations that likely make most Europeans somewhat skeptical about Russia's and Tunkey"s "European bid." A key question the Europeans appear to ask themselves is whether a "tom country" can ever succeed in remaking itself, shaping a new identity, and eventually attaining a new "wholeness".

"A tom country," says Samuel Huntington, "has a single predominant culture which places it in one ciwlization but its leaders want to shift it to another civilization. They say, in effect, "We are one people and belong in one place but we want to change that place." In other words, "the people of torn countries agree on who they are but disagree on which civilization is properly their civilization., 38 Significanty, in Huntington's view; Russia and Turkey are the classical torn countries, for the leadership of both states at one point decided their societies shotild Europeanize - that is, reject their non-Ewropean culture and institutions and "join Europe". Russia has become a torn country at least since Peter the Great, divided over the issue of whether it is a part of European zivilization or is the core of a distinct Eurasian Orthodox civilization. Turkey, after experimenting with the timid Eutopeanizing reforms in the nineteenth century, has become a tom country par excellence since Mustafa Kernal Ataturk who, starting in the 1920s, "led Westernization to its most radical forms.

Huntington's theory is also a handy intellectual tool for comparing the Europeanizing efforts of Russia and Turkey, In the political scientist's opinion, "for a torn country succeśsfully wo redetune its civilizational identity, at least three requirements must be met. First, the political and economic elite of the courtry has to be generally supportive of and 


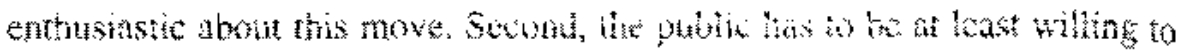
atcquiese in the redefinition of identry. Thint the dominant elements in the hos civiluation, in most cases the west tave to be willing to embrace the convert. "If we look at the two countries through this conceplual prism, we wili see that for many years Turk y hat rior or los mot two of the three minimum requirements, namoly the fust and the secend csupport of the elites and acquicsence of the public). This explairs its quite inpressive progess ayer the last fifty wats. However the elites of the European

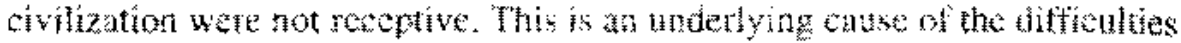

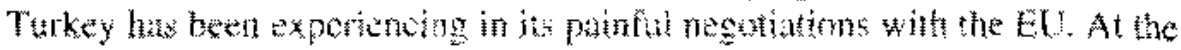

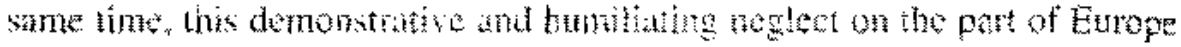

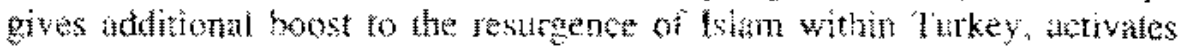

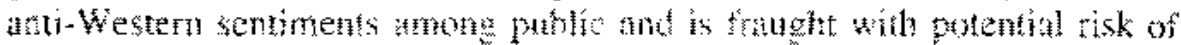

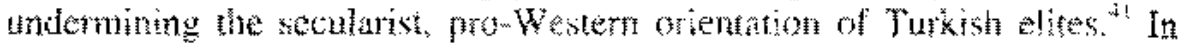
Rusctas's rase, in contrist to the Tubih one, the inability to tully race the forst two requiremente dese the deep division of political ethe and the general public over the isste of Russtan identity thas al ways becn the gravest problem. Thas, the filft path of Rustia"s Europeanization da be explaned

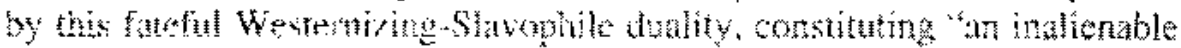

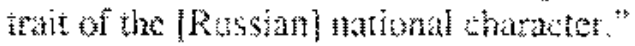

In general, Huntingten is rather skeptical about the pospects of the torn

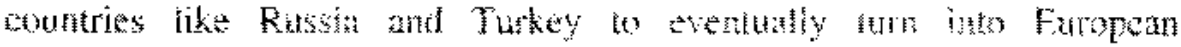

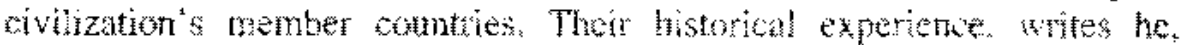

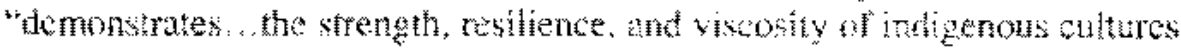

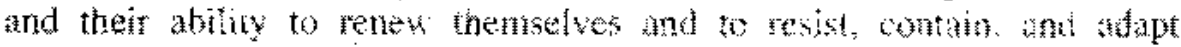

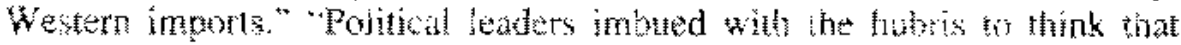
they can fundamentally reshape the culnue of theit weretes ate destined to fall." continues Huntingtan.

While they can introdtes elements of Wostern culture, they

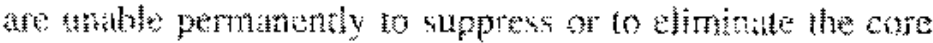
elements of their indiatenots chiture. Conversely the

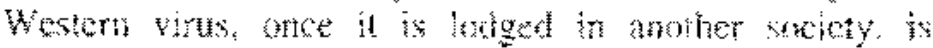

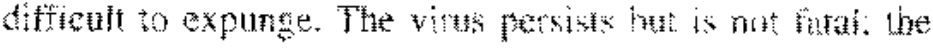

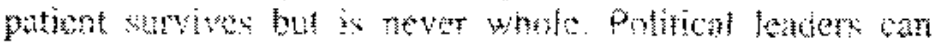

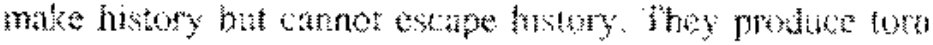

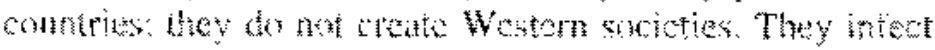

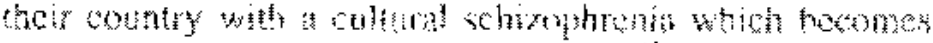

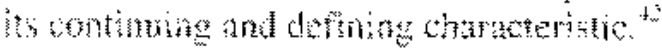


The decision-makers in Brusgels and other EU centers appear to have no less amount of skepticism about the European vocation of the "torn" - or, to nse the other expression, "hernaphrodite" - countries. A clear civilizational bias, some analysts say, can te peresived in how the "new Europe" is being defined. This is how one commentator has recently described -m specifically challenging conventions of political correctness -r the emerging contours of the Enlarged Union; "Christian Europe is part of the new Europe; Orthodox Europe is marginal; Muslim Europe is out. ${ }^{\text {:43 }}$

\section{Condusion}

The latest enlargement decisions have dramatically changed the traditional politicomgeographic "image" of Europe. As one Russian scholar perceptively notes, the EU push to the East is "drastically changing the mentat map of Europe, leading to the 'shrinking' - in fact, disappearanee - of the image of Eastem Europe." Basically, the notion of Eastert Europe, says the analyst, is now associated almost exclusively with Russta. As for the image of Central Europe, it is being viewed now as a "halfway house" - a kind of "purgatory" or "customs office" - on the way to the "real" Europe, Undoubtedly, the notion of Central Europe will soon lose whatever historical or political meaning it used to have and dissolve in the idea of Greater or Unted Europe.

As this discuscion intended to demonstrate, so far "Europe" has been defined in a traditional way, Le. negatively -- in contrast to what is considered non-European. However, so long as there are countries that regard themselves Enopean but are rejected by the members of the EU club on cultural or civilizational grounds, the negative definition of European identity will be constantly challenged. The "outsiders" will continue pushing for the positive constnuetion of "Europe" that is geared to a set of values, principles, and institutions. The debates on Europe are frot from over: they will go on.

\section{Endnotes}

1 fowat! J. Whata, "Where Does Europe End? The Potitiss of NATO and EU Enlargenent," World Affatss, Spring 2002, vol. 164 , no. 4, p. 148 .

"See Martin Kremer. "The EU and the Chatlenge of Defining It External Botders,"

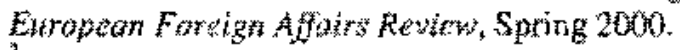

${ }^{3}$ Anthony D. Smith. "Natianal Identity, and the Idea of European Unity" Internatioual Afoirs, 1992, vol. 68, no. 1, p. 75 .

${ }^{4}$ Nornan Davies, Europe: A History Landon: Pirnice, 1997), p. 7. 8. 


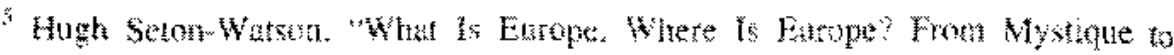

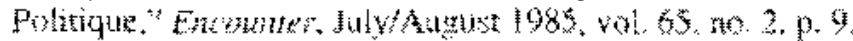

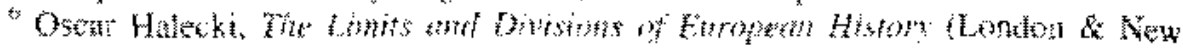

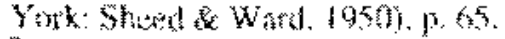

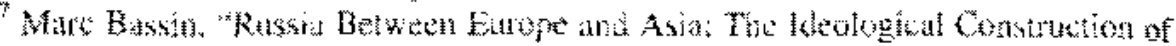

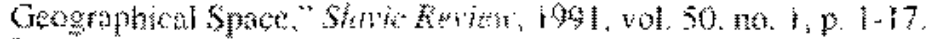

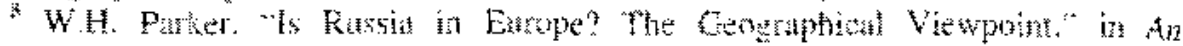

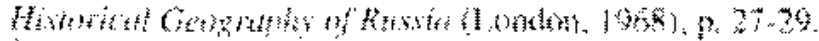

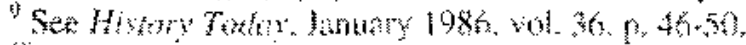

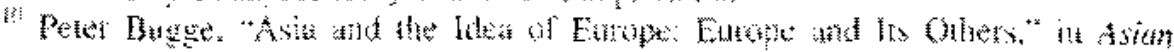

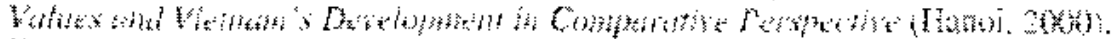

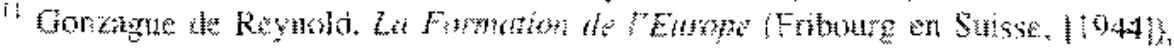
yol. f. D. 55 .

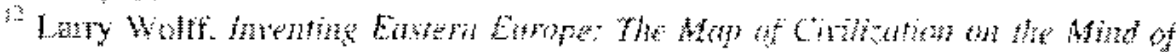

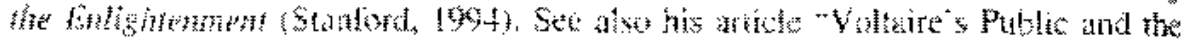

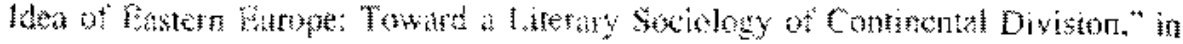

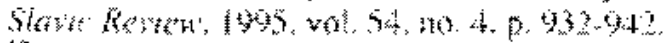

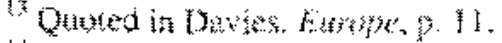

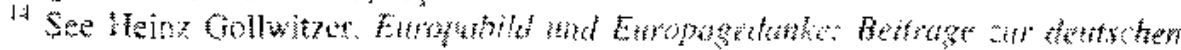

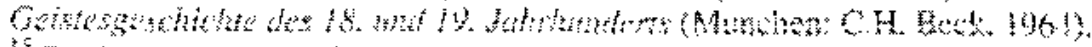

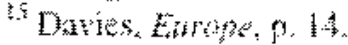

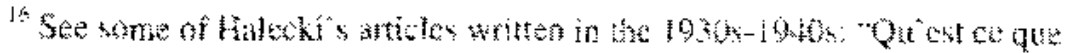

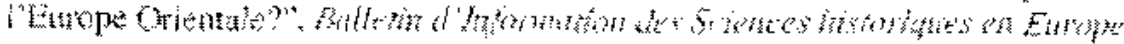

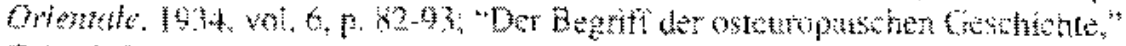

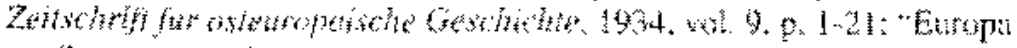

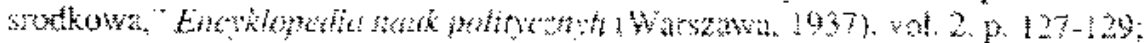

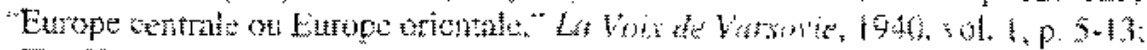

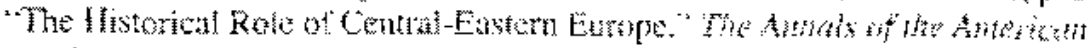

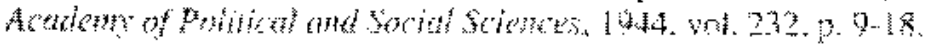

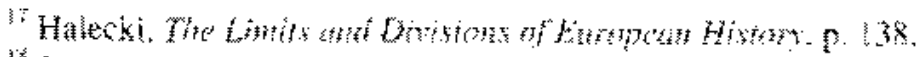

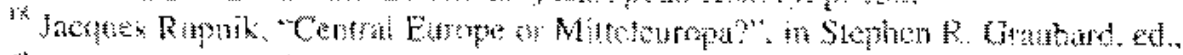

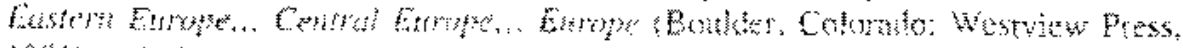

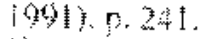

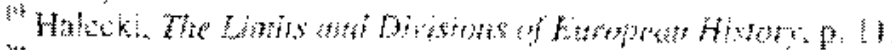

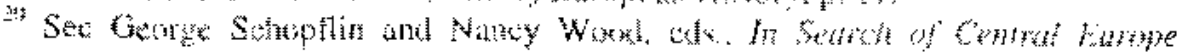

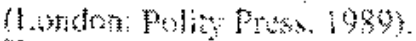

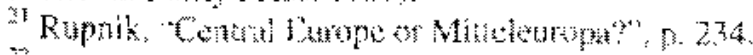

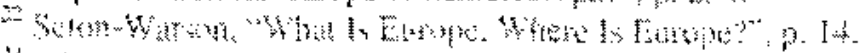

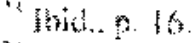

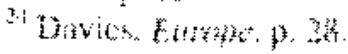


Ast Ismail Cem, Turkey and Europe: Looking to the Future from a Histoncal

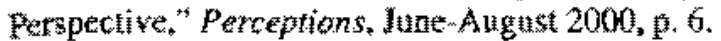

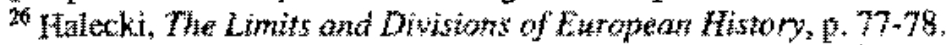

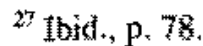

28 Davitis, Europe, p. 646 .

${ }^{29}$ inted, p, 10 .

sat See Seton Watson, "What Is Europe, Where Is Europe?"

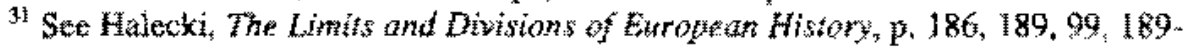
190 ,

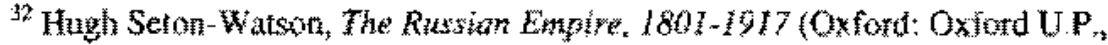
1967), 棒. 1011 .

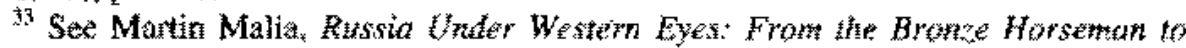

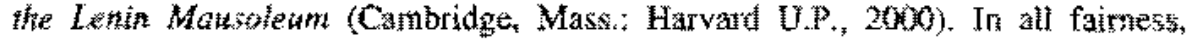

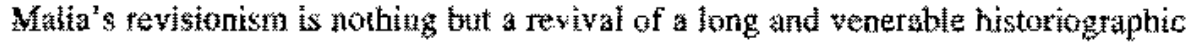
tradition initiated by Russian liberass and postivists in the nimetcenth esntury. They

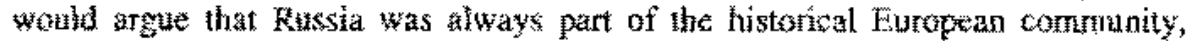
except that is association with the "true" Europe was not equally close in all periods owing to certain factors that delaycd kussia's acyelopment. Rusbian libẹrats contended that Russia never was basicatly different from tite rest ot Furope; the only difference to be admitted, even in corsiteration of the rineteenth-cembry "Etropeanization" of Russia is explained by the thet that, in some respects, Rintia still was, at that time, what Europe zad been before. As T.G. Masaryk once puat it, "Russiand ist was Europa wate"

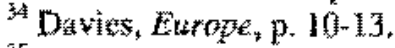

${ }^{35}$ Wiarda, "Where Does Europe Ena?", p. 157 .

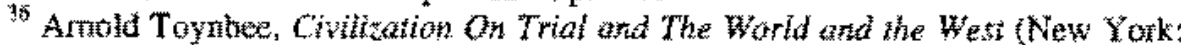
Meridian Books, 1961 ), p. 149-150.

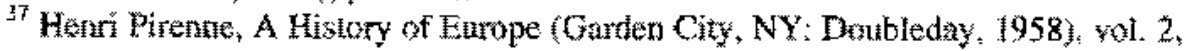
p. 216.

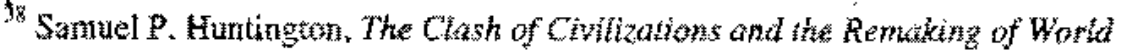
Order new Yort Simon \& Schuster, 1996, p. 138.

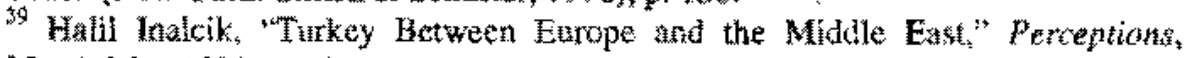
March-May 1998, p. 15.

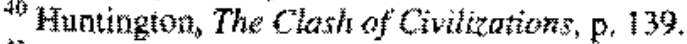

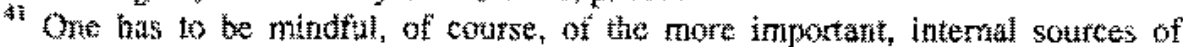
Istan's growing poptarily. As Paffessor Inalcik points on "as a most tecent development. Istarnic tentity inceased vigorously throughout the country, maxinly as a resul of deep disappointment with the socint and exomomic developntent expected frofn a secular Western policy." See ibid p. 17.

* Hurtington, Tha Clash of Civiluzations, p. 154.

4\% Wiarda, "Where Does Europe End?", p. 175" 


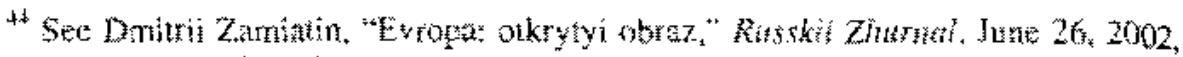

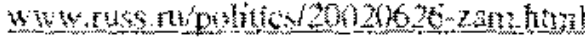

